Creative commons User License: CC BY-NC-ND

Abstracted by: EBSCOhost, Electronic Journals Service (EJS),

Google Scholar, Directory of Open Access Journals (DOAJ),

Journal Seek, Scientific Commons,

Food and Agricultural Organization (FAO), CABI and Scopus
Journal of Agricultural Extension

Vol. 21 (2) June, 2017

ISSN(e): 24086851; ISSN(Print); 1119944X

http://journal.aesonnigeria.org

http://www.ajol.info/index.php/jae

Email: editorinchief@aesonnigeria.org

\title{
Economics of Quail Production in Ilorin, Kwara State, Nigeria
}

https://dx.doi.org/10.4314/jae.v21i2.4

\section{Muhammad-Lawal, Abdulazeez}

Department of Agricultural Economics and Farm Management

University of llorin, llorin, Nigeria

Email: lawaz71@yahoo.com; Phone: +2348035622384

\section{Amolegbe, Khadijat Busola}

Department of Agricultural Economics and Farm Management

University of llorin, llorin, Nigeria

Email: busolatinwol@gmail.com; Phone: +2348054238137

\author{
Abdulsalam, Oladimeji Abdulrasheed \\ Department of Agricultural Economics and Farm Management \\ University of llorin, llorin, Nigeria \\ Email: abdulsalamabdulrasheedo@gmail.com
}

\begin{abstract}
This study assessed the economics of quail production in llorin, Kwara State. Structured questionnaire was used to elicit information from 53 farmers that were selected with the use of a snow-ball sampling technique. Major tools of analysis for the study were descriptive statistics, gross margin analysis and stochastic production frontier model. The study revealed that both males and females estimated at $54.7 \%$ and $45.3 \%$ respectively were actively involved in quail production. About $83.0 \%$ of the respondents were in the age range of 31-50 years. $66 \%$ of the respondents had tertiary education. Furthermore, gross margin analysis shows that an average of $\$ 212,850$ was incurred on variable costs for which feed has the highest percentage (73.0\%). The average net profit of $\$ 172,830$ per production cycle per farm was realised. The mean technical efficiency in quail production was estimated at $60.5 \%$. The major factors affecting the technical efficiency were feed, stock size, experience and farmer's educational level. The research therefore recommended that efforts should be made to reduce feed cost through the establishment of feed mills which are to be monitored by the Standard Organization of Nigeria (SON) to maintain standard.
\end{abstract}

Keywords: Quail production, Quail farmers, Quail in Kwara State.

\section{Introduction}

Livestock sector plays an important role in the Nigerian economy for which over $80 \%$ of the population living in the rural areas are directly or indirectly dependent on agriculture (National Bureau of Statistics, NBS, 2005). The livestock sector is one sector where the poor contribute to the growth directly instead of getting benefit from growth generated elsewhere. The sector serves as an important livelihood activity for most of the farmers, contributes to the health and nutrition of the household, supplements incomes, offers employment opportunities, and serves as a store of 
Creative commons User License: CC BY-NC-ND

Abstracted by: EBSCOhost, Electronic Journals Service (EJS), Google Scholar, Directory of Open Access Journals (DOAJ), Journal Seek, Scientific Commons

Food and Agricultural Organization (FAO), CABI and Scopus
Journal of Agricultural Extension

Vol. 21 (2) June, 2017

ISSN(e): 24086851; ISSN(Print); 1119944X

http://journal.aesonnigeria.org

http://www.ajol.info/index.php/jae

Email: editorinchief@aesonnigeria.org

wealth in times of need. Livestock plays a vital role in the overall economic development of the farm household and nation as a whole as it is important as a source of agricultural diversification and income enhancement.

Quail farming is an important aspect of the livestock sub-sector of the economy. It is also one of the domesticated poultry birds in Nigeria. Quails are small game birds that are used for eggs and meat (DAFF, 2013). Like most domesticated animals, there are a number of quail breeds with varieties of characteristics. Japanese quail was introduced into Nigeria only in 1992 [National Veterinary Research Institute (NVRI), 1994]. The purpose was to make the poultry sub-sector prevalent and help complement domestic chicken production through massive quail farming. Japanese quail is hardy and thrives in small cages and is inexpensive to keep. They are affected by common poultry diseases but are fairly disease resistant. Japanese quail matures in about six (6) weeks and are usually in full egg production by 50 days of age. Its production cycle lasts for about 300 to 320 days. With proper care, hens could lay 200 eggs in their first year of lay. Life expectancy ranges between only two and two-and-a- half years. Japanese quail eggs are mottled brown colour and are often covered with a light blue, chalky material. The average egg weighs about $10 \mathrm{~g}$, about $8 \%$ of the bodyweight of the quail hen.

Quail egg is considered a functional food, as it is a source of protein, vitamins and lipids, such as phospholipids and polyunsaturated fatty acids (Meluzzi et al, 2000). Previous studies (Meluzzi et al, 2000) reported that quail eggs are embedded with vitamins and minerals even with their small size, their nutritional value is three to four times greater than that of chicken eggs. Regular consumption of quail eggs helps fight against numerous diseases as the egg is a natural combatant against digestive tract disorders. Quail eggs strengthen the immune system, promote memory health, increase brain activity and stabilize the nervous system. They help with anemia by increasing the level of hemoglobin in the body while removing toxins and heavy metals (Troutman, 1999;2012). Chinese use quail eggs to help treat tuberculosis, asthma, and even diabetes. Quail eggs can help prevent kidney, liver, and gallbladder stones. The nutritional value of quail eggs is much higher than those offered by other eggs as they are rich sources of antioxidants, minerals, and vitamins, and give us a lot of nutrition than do other foods (Lawani, 2011).

Consumption of animal protein in Nigeria is among the least in the world (lyangbe \& Orewa, 2009). The demand for quail birds and its products in Nigeria is increasing due to its medicinal, nutritional and economic benefits. Therefore, to pace with this increasing demand, effort must be intensified towards increasing the level of production of quails in the country. Quail farming is seen as one of the most promising means to bridge the animal protein gap. The production of quail products is unique and has captured special attention due to its modern day uses such as consumption of its products and often its numerous by-products. However, potentials of poultry production have not been fully exploited because most farmers have restricted themselves to chicken production as compared to other birds which are equally of economic, social and nutritional benefits.

It is important to note that lots of efforts have been put in place to gear-up poultry production in Kwara State in particular and Nigeria in general. However, very little or no effort has been made towards quail production especially in Ilorin, Kwara State. It is therefore pertinent to look into the way and the constraints to production of quail. 
Creative commons User License: CC BY-NC-ND

Abstracted by: EBSCOhost, Electronic Journals Service (EJS),

Google Scholar, Directory of Open Access Journals (DOAJ),

Journal Seek, Scientific Commons,

Food and Agricultural Organization (FAO), CABI and Scopus
Journal of Agricultural Extension

Vol. 21 (2) June, 2017

ISSN(e): 24086851; ISSN(Print); 1119944X

http://journal.aesonnigeria.org

http://www.ajol.info/index.php/jae

Email: editorinchief@aesonnigeria.org

Several studies have been carried out on the production, consumption and some aspects of the profitability of the poultry subsector. A comprehensive picture of the efficiency of quail production and its profitability is however lacking. Hence, this study estimated the profitability of quail production in the study area; examined the technical efficiency of quail production; and determined the constraints to quail production in the study area.

\section{Methodology}

This study was carried out in Ilorin the capital of Kwara State. Kwara State is one of the six states in the North-central Nigeria. The state has sixteen local government areas (LGAs) and covers an area of 74,256sq $\mathrm{km}$. In the state, there are 247,975 farm families with 254, 1242 hectare of cropped area. The annual rainfall pattern across the state extends between the month of April and October with minimum $(1000-1,500 \mathrm{~mm})$ with peak rains in May to June and September to October.

Agriculture is the main stay of the state's economy with over 80 per cent of the population living in rural areas [National Bureau of Statistics (NBS), 2005]. The main crops grown are: sweet potato, cassava, yam, cowpea, groundnut, maize, sorghum, soya beans, melon, okra, melon, pepper, some leafy vegetables and livestock reared include poultry, goats, sheep and cattle. Kwara State population is heterogeneous, attracting different ethnic groups including the Yoruba, Nupe, Baruba, Fulani and Hausa.

\section{Sampling Techniques and Sample Size}

Primary data were used for the study. The data were obtained with the use of structured questionnaire. A snow-ball sampling technique was used in selecting 56 respondents onwhom questionnaire were administered. Responses from 53 respondents were found useful for the study

\section{Data Analysis}

Descriptive statistics such as percentages, frequency distribution, mean, mode, and ratios were used to show the description of the socioeconomic characteristics of the respondents. Gross margin analysis and stochastic frontier model were used Gross margin analysis was used to analyze the costs and benefit of quail farmers. Gross margin is the difference between the gross farm income and the total variable cost. According to Abu, Taanghar and Ekpe (2011) gross margin analysis is a model that is used to estimate the costs, returns, profitability or loss per production.

Mathematically;

$G M=T R-T V C$

Where $\mathrm{GM}=$ Gross Margin; TR= Total Revenue; TVC= Total Variable Cost. The estimation of GM revealed farmers' profitability in the study area. Higher GM could mean higher profitability and vice versa. 
Creative commons User License: CC BY-NC-ND

Abstracted by: EBSCOhost, Electronic Journals Service (EJS),

Google Scholar, Directory of Open Access Journals (DOAJ),

Journal Seek, Scientific Commons,

Food and Agricultural Organization (FAO), CABI and Scopus
Journal of Agricultural Extension

Vol. 21 (2) June, 2017

ISSN(e): 24086851; ISSN(Print); 1119944X

http://journal.aesonnigeria.org

http://www.ajol.info/index.php/jae

Email: editorinchief@aesonnigeria.org

The stochastic frontier model (Battese \& Coelli, 1995) was used to estimate the technical efficiency and analyze the determinants of technical efficiency of quail farmers. It is specified in the implicit form as follows:

$Y_{i}=f\left(X_{i}, \beta\right)+\left(V_{i}-U_{i}\right)$

Where $\mathrm{Yi}$ is the output of the $\mathrm{i}^{\text {th }}$ farm, $\mathrm{X}_{\mathrm{i}}$ is a $\mathrm{K} \times 1$ vector of input quantities of the $\mathrm{i}^{\text {th }}$ farm, $\beta$ is a vector of unknown parameters to be estimated, $V_{i}$ are random variables which are assumed to be normally, independently and identically distributed $\mathrm{N}\left(0, \delta_{v}{ }^{2}\right)$. It is assumed to account for measurement error and other factors not under the control of the farmer. The production model is presented thus:

$Y_{i}=b_{0}+b_{1} X_{1}+b_{2} X_{2}+b_{3} X_{3}+b_{4} X_{4}+b_{5} X_{5}$

Where $Y_{i}=$ production output (\#), $X_{1}=$ labour (man-day), $X_{2}=$ quantity of feed $(\mathrm{kg})$, $X_{3}=$ quantity of drug $(\mathrm{g}), X_{4}=$ quantity of fumigant (litre), $X_{5}=$ stock size (number), $b_{0}, b_{1}, b_{2}, b_{3}, b_{4}, b_{5}$ are coefficients of various inputs with respect to output level.

The inefficiency model is represented by $U_{i}$ and specified as follows:

$U_{i}=d_{0}+d_{1} Z_{1}+d_{2} Z_{2}+d_{3} Z_{3}+d_{4} Z_{4}+d_{5} Z_{5}$

Where $U_{i}=$ technical inefficiency, $Z_{1}=$ age (years), $Z_{2}=$ poultry experience (years), $Z_{3}=$ Membership of association (Yes $=1$, No $=0$ ), $Z_{4}=$ Level of education (Years), $Z_{5}=\operatorname{Sex}($ Male $=1$, female $=0)$ and $d_{0}, d_{1}, d_{2}, d_{3}, d_{4}, d_{5}$ are parameters to be estimated.

A four-point Likert-type scale was used to describe the constraints to quail production in the study area as follows:

- Not a problem (1) - Mild (2) - Severe (3) - Very severe

\section{Results and Discussion}

\section{Socioeconomic and Demographic Characteristics of Respondents}

The socioeconomic and demographic characteristics of the respondents are as described in this sub-section. The major characteristics considered in this study were gender, age, marital status, education, farming experience, access to extension services, and membership of associations. These are as presented in Table 1.

Table 1 indicates that $54.7 \%$ of the respondents were males while $45.3 \%$ were females. The slight difference might be as a result of the quest of the male for additional income that could suffice their family upkeep. Also, age is an important factor among the socioeconomic characteristics in agricultural business as it determines the effectiveness and efficiency of labour availability for the routine farm activities. 
Creative commons User License: CC BY-NC-ND

Abstracted by: EBSCOhost, Electronic Journals Service (EJS),

Google Scholar, Directory of Open Access Journals (DOAJ),

Journal Seek, Scientific Commons,

Food and Agricultural Organization (FAO), CABI and Scopus
Journal of Agricultural Extension

Vol. 21 (2) June, 2017

ISSN(e): 24086851; ISSN(Print); 1119944X

http://journal.aesonnigeria.org

http://www.ajol.info/index.php/jae

Email: editorinchief@aesonnigeria.org

Table 1: Socioeconomic and demographic characteristics of respondents Characteristics

Percentage $(n=53)$

Gender

Male

54.7

Female

45.3

Total

100

Age

$\leq 30$

1.9

31-40

22.6

41-50

60.4

50

15.1

Total

100

Marital Status

Single

7.5

Married

90.6

Widowed

1.9

Total

100

Educational level

Quranic

1.9

Secondary

11.3

Tertiary

66

Adult Education

20.8

Total

100

Experience

$\leq 3$

15.1

6-Apr

67.9

9-Jul

15.1

$>10$

1.9

Total

100

Membership of Association

Yes

22.6

No

79.4

Total

100

Access to Extension Service

Yes

0

No

100

Total

100

Source: Field Survey, 2015 
Creative commons User License: CC BY-NC-ND

Abstracted by: EBSCOhost, Electronic Journals Service (EJS),

Google Scholar, Directory of Open Access Journals (DOAJ),

Journal Seek, Scientific Commons,

Food and Agricultural Organization (FAO), CABI and Scopus
Journal of Agricultural Extension

Vol. 21 (2) June, 2017

ISSN(e): 24086851; ISSN(Print); 1119944X

http://journal.aesonnigeria.org

http://www.ajol.info/index.php/jae

Email: editorinchief@aesonnigeria.org

About $60 \%$ of the respondents were between the age of 41 and 50 years. This is means that most of the quail farmers were in their active and productive years and can easily adopt new innovations to improve production.

Also, education as a measure of human development index is a basic requirement of the welfare of households. All the respondents have one form of education or the other. It is a reflection of quality of labour and may also be responsible for the risk taken ability of the farmers by the adoption of quail production which is still new in the study area. The result also indicates that $66 \%$ of the respondents had tertiary education which determines their exposure and level of adoption of innovation. It was shown that $11.3 \%$ were school leavers while $20.8 \%$ had adult education. Farming experience correlates with the acquisition of good skills in the adoption of innovation in the field of poultry production.

Also, $83 \%$ of the respondents had the poultry experience ranging from 4-9 years. The average number of poultry farming experience of the respondents was 5 years. These results are consistent with the findings of Adisa and Akinkunmi (2012), and Uzokwe and Bakare (2013). Furthermore, membership of association is expected to influence the adoption of quail production and help in sharing of information as well as proffering possible solutions to the various problems that might be faced by the farmers. Furthermore, $77.4 \%$ of the farmers do not belong to any agricultural society, while $22.6 \%$ belongs to either cooperative societies or poultry associations.

\section{Profitability of Quail Products}

This sub-sections presents the costs and returns to quail production in the study area. The details are as presented in Table 2.

\section{Table 2: Gross margin analysis of quail production}

\begin{tabular}{ll} 
Total Revenue & 457,980 \\
Less Total Variable Cost & \\
Feed & 154,800 \\
Labour & 54,000 \\
Transport & 2,500 \\
Drugs and fumigants & 1,550 \\
Gross Margin & \\
Less Total Fixed Cost & 7245,130 \\
Net Farm Income & $\$ 172,830$ \\
\hline
\end{tabular}

Source: Field Survey, 2015

Table 2 shows the costs and returns to quail production of an average farmer per production cycle in the study area. Table 2 shows that the total revenue which is from both eggs and spent layers' proceeds was estimated at $\$ 457,980 /$ cycle/farm. The total variable cost (such as feed, labour, transport and drugs) was estimated at $\# 212,850$. Out of this, the feed constituted $73 \%$ and labour $25 \%$. 
Creative commons User License: CC BY-NC-ND

Abstracted by: EBSCOhost, Electronic Journals Service (EJS),

Google Scholar, Directory of Open Access Journals (DOAJ),

Journal Seek, Scientific Commons,

Food and Agricultural Organization (FAO), CABI and Scopus
Journal of Agricultural Extension

Vol. 21 (2) June, 2017

ISSN(e): 24086851; ISSN(Print); 1119944X

http://journal.aesonnigeria.org

http://www.ajol.info/index.php/jae

Email: editorinchief@aesonnigeria.org

The total fixed cost (depreciated values) was $\$ 72,300$. This cost included the depreciation on fixed assets such as pens, watering can and feeding trough. The gross margin is estimated at $\$ 245,130$ and the net farm income ( $\pi$ ) was 172,830 . On the average, a profit of $\$ 172,830$ is recorded per farm per production cycle. This reveals that quail production in the study area is averagely profitable, because the farmers are making a net farm income which covers the costs incurred on the farms. This result is in line with the findings of Onyewuchi, Offor and Okoli (2013) that quail meat and egg production are profitable.

\section{Production Efficiency}

The level of efficiency of quail production and its determinants are presented in Tables 3 and 4.

\section{Technical Efficiency of Quail Farmers}

Table 3 shows the distribution of technical efficiency among the quail farmers. There was great variation in the levels of efficiency. It shows the minimum estimated efficiency of $39.4 \%$, while the maximum efficiency was $99.9 \%$ and the mean technical efficiency is $60.5 \%$.

Table 3: Summary of technical efficiency estimates of quail farmers in llorin, Kwara State

\begin{tabular}{ll}
\hline Level of Efficiency & Percentages $(\mathbf{n = 5 3})$ \\
\hline$<50$ & 32.08 \\
$50-59.99$ & 28.31 \\
$60-69.99$ & 16.98 \\
$70-79.99$ & 9.43 \\
$80-89.99$ & 3.77 \\
$90 \&$ above & 9.43 \\
\hline
\end{tabular}

Mean TE: 0.6053 (Min TE: 0.3937, Max TE: 0.9999)

Source: Field Survey, 2015

The mean level of technical efficiency indicates that on average the output falls $39.5 \%$ short of the maximum possible level. Therefore, in the short run, it is possible to increase production by an average of $39.5 \%$ by adopting efficient farming techniques. In other words, this mean value indicates that opportunity still exists for increasing productivity and income through increased efficiency in resource utilization. More so, according to Hamra (2010) proper management such as vaccination, cleanliness and sanitization ensures efficient production and good quality products (meat or eggs).

The result shows that $60.4 \%$ of the farmers fall below the $60.5 \%$ mean efficiency level, while $22.6 \%$ of them have their technical efficiencies greater than the mean technical efficiency. A mean technical efficiency of $60.5 \%$ obtained in this study is good. However, a gap exists between the efficiency of the best technically efficient farmer $(99.9 \%)$ and the average farmer $(60.5 \%)$. 
Creative commons User License: CC BY-NC-ND

Abstracted by: EBSCOhost, Electronic Journals Service (EJS),

Google Scholar, Directory of Open Access Journals (DOAJ),

Journal Seek, Scientific Commons,

Food and Agricultural Organization (FAO), CABI and Scopus
Journal of Agricultural Extension

Vol. 21 (2) June, 2017

ISSN(e): 24086851; ISSN(Print); 1119944X

http://journal.aesonnigeria.org

http://www.ajol.info/index.php/jae

Email: editorinchief@aesonnigeria.org

Table 4: Maximum Likelihood Estimate of the Stochastic Frontier Production Function for Quail Farmers in Ilorin, Kwara State, Nigeria

\begin{tabular}{|c|c|c|c|c|}
\hline Variables & Parameters & Coefficients & Standard Errors & t-ratio \\
\hline \multicolumn{5}{|c|}{ Stochastic Frontier } \\
\hline Constant & $b_{0}$ & 12.412 & 0.164 & 75.807 \\
\hline Labour & $b_{1}$ & 0.001 & 0.001 & 1.128 \\
\hline Feed & $b_{2}$ & 0.001 & 0.0002 & $5.907^{* * *}$ \\
\hline Drug & $b_{3}$ & -0.0003 & 0.0003 & -1.112 \\
\hline Fumigants & $b_{4}$ & -0.405 & 0.154 & $-2.636^{* * *}$ \\
\hline \multicolumn{5}{|c|}{ Inefficiency Model } \\
\hline Constant & $\mathrm{d}_{0}$ & 0.516 & 0.475 & 1.087 \\
\hline Age & $d_{1}$ & -0.041 & 0.034 & -1.223 \\
\hline Experience & $d_{2}$ & 0.013 & 0.007 & $1.938^{*}$ \\
\hline Association & $d_{3}$ & -0.171 & 0.128 & -1.332 \\
\hline Education & $\mathrm{d}_{4}$ & 0.171 & 0.074 & $2.319 * *$ \\
\hline Sex & $d_{5}$ & 0.081 & 0.049 & 1.640 \\
\hline \multicolumn{5}{|c|}{ Variance Parameters } \\
\hline Sigma-squared & & 0.040 & 0.007 & 5.543 \\
\hline Gamma & & 0.999 & 0.003 & 314.864 \\
\hline
\end{tabular}

Table 4 shows the results of the efficiency and inefficiency models on the production of quail in Ilorin, and also the variables which were statistically significant and affect production efficiency. The estimated gamma is significant at $1 \%$ of probability. This confirms that the technical inefficiency effects are significant in the estimated model. From the estimated equation and in consonance with a priori expectation, the coefficient of the value of feed is positively and statistically significant. This implies that feed has a great influence on poultry production and performance. Feed has the highest coefficient and this tends to suggest largest impact on output.

Fumigant and stock size are also statistically significant at $1 \%$ and $5 \%$ levels respectively. This tends to suggest that fumigation is essential to prevent an outbreak of disease. The stock size will also determine the output holding other factors constant, because the more the stock size, the more the likelihood of having larger output.

Poultry experience and level of education of the respondents were statistically significant to technical efficiency. This is in conformity with a priori expectation that efficiency increases with experience.

\section{Constraints to Quail Production}

This sub-section highlights the major constraints to quail production in the study area. The details of the constraints to production are as presented in Table 5. 
Creative commons User License: CC BY-NC-ND

Abstracted by: EBSCOhost, Electronic Journals Service (EJS),

Google Scholar, Directory of Open Access Journals (DOAJ),

Journal Seek, Scientific Commons,

Food and Agricultural Organization (FAO), CABI and Scopus
Journal of Agricultural Extension

Vol. 21 (2) June, 2017

ISSN(e): 24086851; ISSN(Print); 1119944X

http://journal.aesonnigeria.org

http://www.ajol.info/index.php/jae

Email: editorinchief@aesonnigeria.org

Table 5: Quail production constraints

\begin{tabular}{lll}
\hline Constraints & Mean & S.D \\
\hline Poor weight gain & 1.08 & 0.267 \\
Scarcity of vaccine & 1.11 & 0.32 \\
Pest and disease problem & 1.66 & 0.478 \\
Poor Price & 2.45 & 0.539 \\
Unconducive weather & 2.19 & 0.483 \\
Access to Required Species & 1.15 & 0.456 \\
Difficulty of managing quail with other birds & 1.09 & 0.354 \\
Feed quality & 2.89 & 0.467 \\
Price of feed & 2.98 & 0.239 \\
Access to Quality Feed & 2.38 & 0.596 \\
Egg distribution and sales & 3.45 & 0.607 \\
High mortality & 1.28 & 0.533 \\
Access to Point of Lay & 1.08 & 0.267 \\
Access to Extension Services & 2.36 & 0.834 \\
\hline
\end{tabular}

Source: Field Survey, 2015

Table 5 shows the likely constraints tested in terms of severity to quail production in Ilorin Kwara State. It shows the frequencies of the various notable constraints to quail production in the study area. As indicated in Table 5, distribution and sales of quail and its products has the highest mean of 3.45. Prominent among other constraints are fluctuations in feed price (2.98), variation in feed quality (2.89) and poor price of quail products (2.45).

These may contribute to the decline in production and decision of some of the farmers to call it a quit. Other factors such as poor weight gain, scarcity of vaccines, problem of pests and diseases, difficulty in managing quail with other birds and high mortality rate with lower mean value i.e. not up to 2 are considered not a problem and have no negative effect on production according to most of the farmers in the study area. This is in line with the findings of Siddique and Mandal (1996) that quail production is bedeviled by so many problems and that the profitability can be increased if these problems can be minimized. Also, adequate management such as disease control, proper waste management and adequate feeding ensures efficient production.

\section{Conclusion and Recommendations}

Quail production is a profitable venture in Kwara State; though the performance is still not at its best. The efficiency of production is being constrained by the distribution and sales of the products, fluctuation in feed price, variation in feed quality and poor price of products amongst others. However, opportunity still exists for increasing productivity and income through increased efficiency in resource utilization. Hence, government, should support the farmers by assisting veterinary research institutes to come up with quail breeds that are highly prolific and disease resistant. Any measure adopted that will reduce the cost of production such as the stock cost and that of the feed with highest percentage in production cost will invariably increase the farmer's profit margin. 
Creative commons User License: CC BY-NC-ND

Abstracted by: EBSCOhost, Electronic Journals Service (EJS),

Google Scholar, Directory of Open Access Journals (DOAJ),

Journal Seek, Scientific Commons,

Food and Agricultural Organization (FAO), CABI and Scopus
Journal of Agricultural Extension

Vol. 21 (2) June, 2017

ISSN(e): 24086851; ISSN(Print); 1119944X

http://journal.aesonnigeria.org

http://www.ajol.info/index.php/jae

Email: editorinchief@aesonnigeria.org

There is therefore the need to establish standard feed mill to make the feed readily available to the farmers at reduced cost and improve farmers' efficiencies. In addition, Standard Organization of Nigeria (SON) should keep an eye on those companies so as to maintain standard. Finally, there is the need to enlighten the general public about the nutritional, medicinal and economic value of this very important bird to increase consumption and usage of the products thereby creating ready market for the products and increasing production.

\section{Reference}

Abu, G.A., Tanghar, T.E \& Ekpe, I.D. (2011) "Proximate Determinants of Farmers WTP (Willingness to pay) for Soil Management Information Services in Benue State Nigeria. African Journal of Agricultural Research. 6 (17): 4057-4064.

Adisa, B.O. \& J.A. Akinkunmi, 2012. Assessing participation of women in poultry production as a sustainable livelihood Choice in Oyo State, Nigeria. Int. J. Plant Anim. Environ. Sci., 2: 73-82.

Battese, G.E. \& Coelli. T.J. (1995). A model for technical inefficiency effects in a stochastic frontier production function for panel data. Empirical Econ. 20: 325332

DAFF. (2013). Structure and Dynamic of Quails. Commonwealth of Australia, 1-5.

Hamra C.F. (2010). An Assessment of the Potential Profitability of Poultry Farms: A Broiler Farm Feasibility Case Study. Research Paper Submitted to the Faculty of The University of Tennessee at Martin

lyangbe C.O \& Orewa S.I (2009) Determinants of Daily Protein Intake among Rural and Low-Income Urban Households in Nigeria American-Eurasian Journal of Scientific Research 4 (4): 290-301

Lawani, P. (2011). Quail Egg Nutrition. http://www.buzzle.com/articles/quail-eggnutrition.html Accessed 15th April 2012

Meluzzi, A., F. Sirri, G. Manfreda, N. Tallarico \& A. Franchini (2000). Effects of dietary vitamin $E$ on the quality of table eggs enriched with $n-3$ long - chain fatty acids. Poult. Sci. 79: $539-545$.

National Bureau of Statistics (NBS) (2005): Poverty Profile for Nigeria. Federal Republic of Nigeria.

National Veterinary Research Institute (NVRI), 1994.Farmer training on quail production \& health management. National Veterinary research Institute, Vom, Nigeria, Pp:44.

Onyewuchi, U. U., Offor, I. R. and Okoli, C. F. (2013) Profitability Of Quail Bird And Egg Production In Imo State Nigerian Journal of Agriculture, Food and Environment. 9(1):40-44

Siddique S. A \& Mandal M.A.S (1996). Economics of Japanese Quail Farming In Dhaka Metropolitan City Bangladesh J. Agric. Econs. XIX, 1\& 2 (1996): 71-84

Uzokwe, U.N. \& E.A. Bakare, 2013. The effects of climate variability on poultry production in Ose Local government area of Ondo State, Nigeria: Socioeconomic characteristics and perceptions of farmers. Int. J. Agric. Biosci., 2: 39-44. 